\title{
Polynucleotide phosphorylase is involved in the control of lipopeptide fengycin production in Bacillus subtilis
}

\author{
Yazen Yaseen ${ }^{1} \cdot$ Awa Diop $^{1} \cdot$ Frédérique Gancel $^{1} \cdot$ Max Béchet $^{1} \cdot$ Philippe Jacques $^{1} \cdot$ Djamel Drider $^{1}$
}

Received: 24 August 2017 / Revised: 18 January 2018 / Accepted: 23 January 2018 / Published online: 8 February 2018

(c) Springer-Verlag GmbH Germany, part of Springer Nature 2018

\begin{abstract}
Bacillus subtilis is a wealth source of lipopeptide molecules such as iturins, surfactins and fengycins or plipastatins endowed with a range of biological activities. These molecules, designated secondary metabolites, are synthesized via non-ribosomal peptides synthesis (NRPS) machinery and are most often subjected to a complex regulation with involvement of several regulatory factors. To gain novel insights on mechanism regulating fengycin production, we investigated the effect of the fascinating polynucleotide phosphorylase (PNPase), as well as the effect of lipopeptide surfactin. Compared to the wild type, the production of fengycin in the mutant strains B. subtilis BBG235 and BBG236 altered for PNPase has not only decreased to about 70 and $40 \%$, respectively, but also hampered its antifungal activity towards the plant pathogen Botrytis cinerea. On the other hand, mutant strains BBG231 ( $\left.r f A A^{-}\right)$and BBG232 (srfAC $\left.{ }^{-}\right)$displayed different levels of fengycin production. BBG231 had registered an important decrease in fengycin production, comparable to that observed for BBG235 or BBG236. This study permitted to establish that the products of pnpA gene (PNPase), and $s r f A A^{-}$(surfactin synthetase) are involved in fengycin production.
\end{abstract}

Keywords Polynucleotide phosphorylase $\cdot$ Fengycin $\cdot$ Surfactin $\cdot$ B. subtilis

\section{Introduction}

Bacillus subtilis is known to produce a wealth of active compounds through its secondary metabolism machinery (Sinchaikul et al. 2002). According to Stein (2005) and Chen et al. (2007), about $4-5 \%$ of B. subtilis genome (8.5\% for Bacillus amyloliquefaciens) is thought to be devoted to synthesis of antimicrobial compounds including the lipopeptides group, which are defined as non-ribosomally synthesized peptides (NRPS) (Nakano et al. 1991). Fengycin or plipastatin contains ten amino acids, which are incorporated by five NRP Synthetases (Fen1 to Fen5/Pps1-5) (Steller et al. 1999; Jacques 2011). The fengycin operon is composed of five open reading frames (ORFs) named fenA-E (or ppsA-E) (Steller et al. 1999; Tsuge et al. 1999; Jacques 2011). The

Communicated by Djamel DRIDER.

Djamel Drider

djamel.drider@univ-lille1.fr

1 Université de Lille, INRA, Université d'Artois, Université du Littoral-Côte d'Opale, EA 7394 - ICV-Institut Charles Viollette, F-59000 Lille, France expression of lipopeptide operons involves complex regulatory machinery, which is linked to a quorum sensing as reported for surfactin or mycosubtilin, a member of iturins family (Nakano et al. 1991; Duitman et al. 2007).

It has been reported that in many Bacilli, besides DNA coding for fengycin, there is at least one other lipopeptidecodifying DNA, and surfactin is most often this additional lipopeptide (Roongsawang et al. 2002, 2010; Kim et al. 2010). As recalling fact, and depicted in Fig. 1, surfactin operon contains four large ORFs coding for surfactin synthetases and designated $\operatorname{srfAA}, \operatorname{srfAB}, \operatorname{srfAC}$ and $\operatorname{srf} A D$ (Galli et al. 1994; Lee et al. 2007). The regulatory comS gene which is requested for $B$. subtilis competence, is located within the region coding for the fourth amino acid activation domain of $\operatorname{srfAB}$, and it is co-expressed with the srfA operon (Liu et al. 1996; Nakano and Zuber 1991; Hamoen et al. 1995; Jacques 2011). In terms of mRNA stability, only the effect of PNPase on surfactin has been yet reported (Luttinger et al. 1996).

PNPase catalyzes the $3^{\prime}-->5^{\prime}$ phosphorolysis of polyribonucleotides leading to nucleoside diphosphates (NDPs), and the $5^{\prime}-->3^{\prime}$ polymerization of ribonucleoside diphosphates, releasing inorganic phosphate. PNPase catalytic activity is 


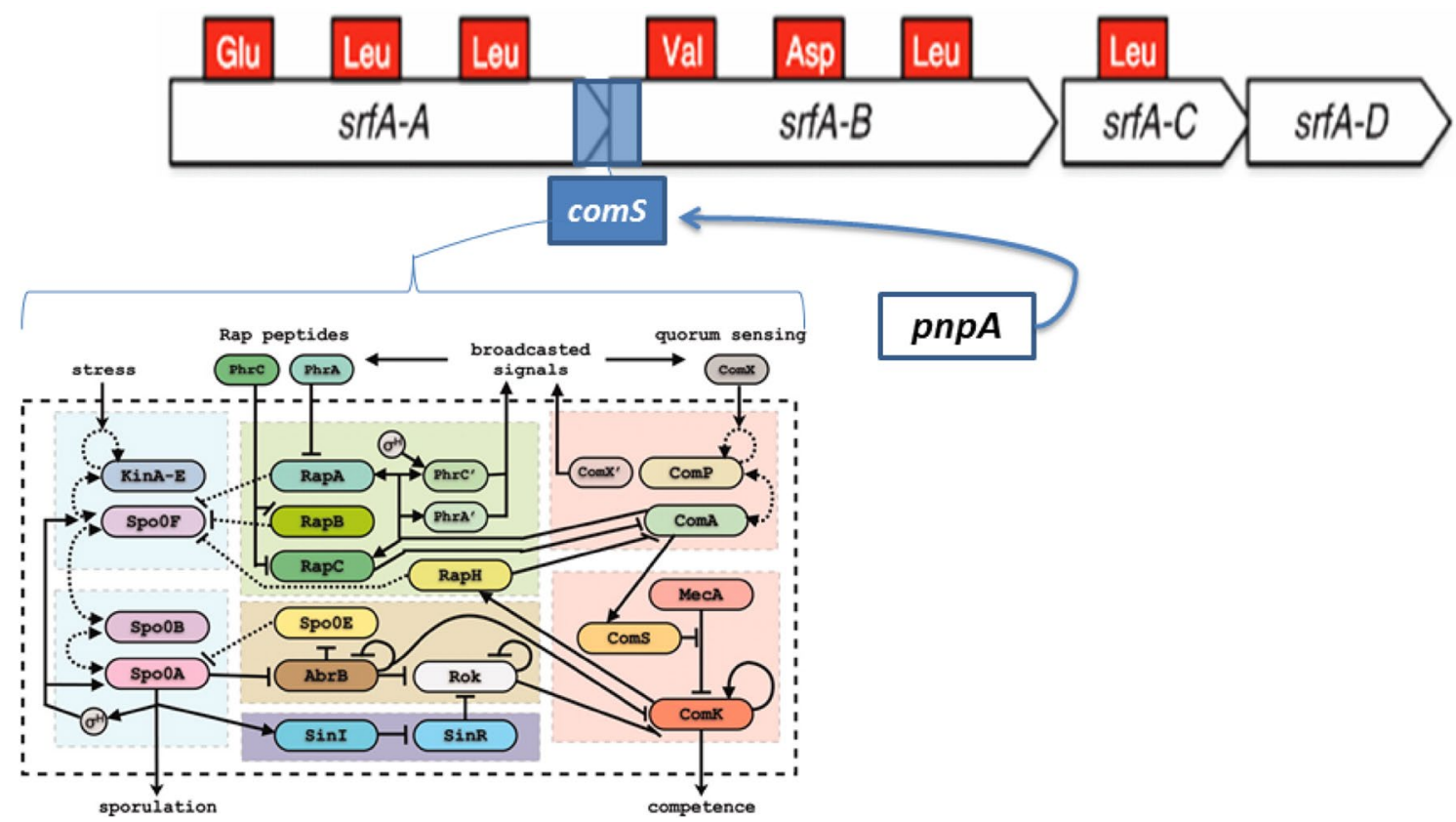

Fig. 1 Schematic regulatory interaction between the operon of surfactin including the genes comS and pnpA in B. subtilis [adapted from Schultz et al. 2009; Jacques 2011]

$\mathrm{Mg}^{2+}$-dependent and inhibited by high $\mathrm{Mn}^{2+}$ concentration. According to Kakiuchi et al. (1979), a large variety of ribonucleoside diphosphatases may serve as template for the polymerization reaction.

PNPase has been studied by Severo Ochoa and Arthur Kornberg, who were awarded for Nobel Prize in 1959. After this discovery, PNPase remains still a fascinating enzyme playing a multifaceted role in bacterial cells. Previously, it was established that accumulation of mRNA decay intermediates was associated with strains lacking PNase activity, underlining the role of this major ribonuclease (Liu et al. 2014). Recent review from Briani et al. (2016) listed the allocated functions for PNPase. Briefly, these functions include the control of mRNA decay, processing of rRNA and maturation of tRNA, stability control of small noncoding RNAs, control of growth at low temperature in different Gram-negative and Gram-positive bacteria, or biofilm control.

Understanding gene regulation in bacteria is an important feature for designing the genetic circuit promoting overproduction of molecules of industrial interest such as lipopeptides, which are expected to be the next generation of bio-pesticides. Within the lipopeptides repertoire, fengycin is considered as promising biocontrol agent. Indeed, different biological functions were allocated to this lipopeptide antibiotic, including growth of filamentous fungi, control of apoptosis and necrosis (Tang et al. 2014), role in the development and progress of colon cancer via the cells apoptosis and cell cycle targeting Bax/Bcl-2 pathway (Cheng et al.
2016), coating for preventing fungal infection associated with silicone medical devices (Ceresa et al. 2016), and protection of Caenorhabditis elegans from Gram-positive infection (Iatsenko et al. 2014).

The present work aimed at showing the role of PNPase on fengycin production, as well as that of the operon coding for surfactin on fengycin production.

\section{Materials and methods}

\section{Bacterial strains, plasmids and primers}

Plasmids and bacteria used in this study are listed in Table 1 . All primers used for genetic construction or checking of derivative DNA are depicted in Table 2.

\section{Bacillus engineering and growth conditions}

All strains derived from $B$. subtilis 168 were transformed by natural competence method (Sambrook and Russell 2001). Transformation of BBG201 was performed with a modified electroporation method requiring trehalose (Cao et al. 2011).

Bacillus strains and Escherichia coli JM109 were grown in Luria-Bertani medium (LB), at $37{ }^{\circ} \mathrm{C}$ under shaking, at $130 \mathrm{rev} \mathrm{min}^{-1}$. Media were supplemented, when necessary, with apramycin, sulphate salt $\left(100 \mu \mathrm{g} \mathrm{ml}^{-1}\right)$, erythromycin $\left(1 \mu \mathrm{g} \mathrm{ml}^{-1}\right)$, chloramphenicol $\left(1 \mu \mathrm{g} \mathrm{ml}^{-1}\right)$, phleomycin $(4 \mu \mathrm{g}$ $\left.\mathrm{ml}^{-1}\right)$, or neomycin, trisulphate salt $\left(5 \mu \mathrm{g} \mathrm{ml}^{-1}\right)$. All these 
Table 1 Strains and plasmids used in this study

\begin{tabular}{|c|c|c|}
\hline Plasmid or bacterial strain & Plasmid description or genotype (phenotype) & Reference \\
\hline pGEM-T easy & $b l a^{R}$ & Promega Corp. \\
\hline pMUTIN-GFP+ & $b l a^{R}, e^{R}{ }^{R}, g f p(6192 \mathrm{bp})$ & $\begin{array}{l}\text { Bacillus Genetic Stock } \\
\text { Center, Columbus, } \\
\text { OH, USA }\end{array}$ \\
\hline pBG330 & $\begin{array}{l}\text { pGEM-T Easy, KpnI-XmaIII ribC-pnpA amplicon from B. subtilis BBG21; bla }{ }^{R} \text {, } \\
\text { (4625 bp) }\end{array}$ & This study \\
\hline pBG331 & $\begin{array}{l}\text { pGEM-T Easy, KpnI-XmaIII hxlR -srfAA amplicon from B. subtilis BBG21; bla }{ }^{R} \text {, } \\
\text { (3903 bp) }\end{array}$ & This study \\
\hline pBG332 & $\begin{array}{l}\text { pGEM-T Easy, EcoRI-HindIII srfAC-srfAC amplicon from B. subtilis BBG21; bla }{ }^{R} \\
\text { (4630 bp) }\end{array}$ & This study \\
\hline pBG333 & $\begin{array}{l}\text { pMUTIN-GFP+, bla }{ }^{R}, e r m^{R}, \text { KpnI-XmaIII ribC-pnpA amplicon from B. subtilis BBG21 } \\
\text { (7,801 bp) }\end{array}$ & This study \\
\hline pBG335 & pOJ206, bla ${ }^{R}, a^{R}$, EcoRI-HindIII srfAC-srfAC amplicon from B. subtilis BBG21 & This study \\
\hline pBG334 & $\begin{array}{l}\text { pMUTIN-GFP }+b l a^{R}, e r m^{R}, \text { KpnI-XmaIII hxlR-srfAA amplicon from B. subtilis BBG21, } \\
\text { (7078 bp) }\end{array}$ & This study \\
\hline B. subtilis $\mathrm{BBG} 21$ & Spontaneous mutant of $B$. subtilis ATCC 21332, fen+, srf+ & Fahim et al. (2012) \\
\hline B. subtilis $\mathrm{BBG} 258$ & cat $^{R}$, B. subtilis $168 s f p+$, pps,+ srf+ + & Dhali (2016) \\
\hline BBG201 & tet $^{R}$, B. subtilis $\mathrm{BBG} 21(\mathrm{pMMComK})$ & Yaseen et al. (2016) \\
\hline BBG231 & erm $^{R}$, B. subtilis BBG21 srfAA::(srfAA/BBG21-gfp-erm $\left.{ }^{R}\right)$ & This study \\
\hline BBG232 & 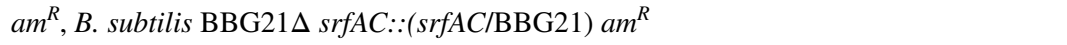 & This study \\
\hline BBG235 & erm $^{R}$, B. subtilis BBG201 $1 p n p A::\left(p n p A / B B G 21-\right.$ gfp-erm $\left.{ }^{R}\right)$ & This study \\
\hline BBG236 & 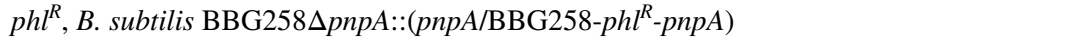 & This study \\
\hline Escherichia coli JM109 & $\begin{array}{l}\text { recAl, endA1, gyrA96, thi, hsdR17, supE44 } \Delta(\text { lac-proAB }) F^{\prime}[\text { traD36, proAB+, lacIq, } \\
\text { lacZ } \Delta \mathrm{M} 15]\end{array}$ & Promega Corp. \\
\hline
\end{tabular}

$a m^{R}$, resistance to apramycin; $b l a^{R}$, resistance to ampicillin; $\mathrm{erm}^{R}$, resistance to erythromycin; $p h l^{R}$, resistance to phleomycin; and tet ${ }^{R}$, resistance to tetracycline

antibiotics were purchased from Sigma-Aldrich (St. Louis, MO, USA). The hemolytic activity was detected upon overnight growth of Bacillus strains on LB blood plates (Coutte et al. 2010). Microbial growth was monitored by optical density OD $_{600 \mathrm{~nm}}$ with an UVIKON 940 spectrophotometer (Kontron Instruments, Plaisir, France). Landy medium (Landy et al. 1948) containing $100 \mathrm{mM} 3$-(N-morpholino) propanesulfonic acid (MOPS) was used as basic medium for lipopeptides production with 10\% filling ratio of Erlenmeyer, at $30{ }^{\circ} \mathrm{C}$ and $160 \mathrm{rev} \mathrm{min}^{-1}$ (Hussein 2011).

\section{DNA manipulation}

Polymerase chain reaction (PCR) was performed using the PCR Master Mix (2X) (Thermo Scientific Fermentas, Villebon sur Yvette, France), as a mixture of Taq DNA polymerase. DNA extraction was performed with the Wizard ${ }^{\circledR}$ Genomic DNA Purification Kit (Promega Corp., Madison, WI, USA). PCR products were cloned into the pGEM-T Easy vector (Promega Corp.). Plasmid extraction was carried out with the GeneJET Plasmid DNA Purification Kit (Thermo Scientific Fermentas). Ligation of inserts to different vectors was effected using the DNA Ligation Kit Mighty Mix from Takara (Ozyme, Saint Quentin en
Yvelines, France). Restriction endonucleases were supplied by Thermo Scientific Fermentas. Recovery of DNA from agarose gels was performed with GeneJET Gel Extraction kit (Thermo Scientific Fermentas). All the sequences were checked by DNA sequencing realized at Eurofins Genomics (Ebersberg, Germany).

\section{Construction of polynucleotide phosphorylase-deficient strains}

The DNA amplicon obtained from B. subtilis BBG21 with primers ribC fwd and pnpA $y l x Y$ rev (Table 2), was cloned into pGEM-T Easy vector. The resulting plasmid pBG330 was KpnI-XmaIII double digested and inserted between the $K p n I$ and XmaIII sites of pMUTIN-GFP ${ }^{+}$vector, leading to the recombinant plasmid pBG333, which was successfully transferred into $B$. subtilis BBG201 by electroporation procedure (Cao et al. 2011). The resulting derivative was designated BBG235.

Two DNA fragments from $B$. subtilis BBG258, a derivative of $B$. subtilis 168 , were amplified using primers $p n p A$ Fw, pnpA delta Rv and the primers pnpA delta Fw, pnpA Rv (Table 2). Notably, primers P3 and P5 permitted to amplify the fragment $\mathrm{k} 7$ containing the phleomycin resistance gene. 
Table 2 PCR primers used for genetic constructions

\begin{tabular}{|c|c|c|}
\hline Primer & Primer sequence $\left(5^{\prime} \rightarrow 3^{\prime}\right)$ & $\begin{array}{l}\text { Amplicon } \\
\text { length } \\
\text { (bp) }\end{array}$ \\
\hline HxlR B.s. BBG21 KpnI fwd & CACAGGGAAGTGGTACCAGT & 902 \\
\hline srfAA B.s. BBG21 XmaIII rv & AATCGGCCGCTCAACAAG & \\
\hline srfAC B.s. BBG21 EcoRI fwd & GAATTCGATGAGGAAGCCAAC & 1620 \\
\hline srfAC B.s. BBG21 HindIII rv & CTTCAAACAAAAGCTTCACTGG & \\
\hline pnpA B.s. KpnI fwd & ATATCGGTACCGCGCTTCAA & 1551 \\
\hline pnpA B.s. XmaIII rv & CGGCCGTCCGGTCTTACTTT & \\
\hline pnpA B.s. ribC fwd & CCTTAATGTGCAGCACGCAG & 3409 \\
\hline pnpA B.s. ylxY rv & TTTTAATCAATGTGGCATGG & \\
\hline pnpA fwd & TCATGGTGATAAAAGAGGGC & 1069 \\
\hline pnpA Delta rv & $\begin{array}{l}\text { CGACCTGCAGGCATGCAAGCTACCGT } \\
\text { AGCGGATCATCACAGCACCATTTGC }\end{array}$ & \\
\hline pnpA Delta fwd & $\begin{array}{l}\text { GCTCGAATTCACTGGCCGTCGGCAAATG } \\
\text { GTGCTGTGATGATCCGCTACGGTACAAGGA } \\
\text { CGAGTGAATTTATCCCGCAAAGC }\end{array}$ & 1039 \\
\hline pnpA rv & TCGGATGCATTAAAATCATGGC & \\
\hline K7 P3 & AGCTTGCATGCCTGCAGGTCG & 2660 \\
\hline K7 P5 & CGACGGCCAGTGAATTCGAGC & \\
\hline PpsA q fw & GAGCCTGAGGTCAGCTTTAAT & 112 \\
\hline PpsA q rv & GTTCTCTCTCACCCGCTATTTC & \\
\hline PpsB q fw & CAGACTACACCGGGCATATT & 95 \\
\hline PpsB q rv & CGGGCTGATCCGTTACTATTT & \\
\hline $\mathrm{PpsC}$ q fw & AGGACATGAATGAGGCAGAAG & 123 \\
\hline PpsC q rv & СTCTTGCTGGGTAGGTGTATTT & \\
\hline PpsD q fw & GCAGCCGGAAGATGTAAAGA & 103 \\
\hline PpsD q rv & GAGTTCGGTATGCGGACATATAG & \\
\hline PpsE q fw & CCAGATCTCGCGCTTCATAATA & 84 \\
\hline PpsE q rv & CCCGCATAGTCTCTCTTCATTT & \\
\hline
\end{tabular}

The three fragments were ligated using the joint PCR program NEBuilder Assembly (New England Biolabs Inc., Ipswich, MA, USA). After natural competence transformation, the BBG236 strain was obtained.

\section{Construction of $B$. subtilis altered in surfactin operon}

Fragments of $h x l R$-srfAA and $s r f A C-s r f A C$ were amplified by PCR using primers HxlR B.S. BBG21-SrfAA B.S. BBG21 and primers SrfAC fw B.S. BBG21-SrfAC rv B.S. $B B G 21$, respectively. These two fragments were cloned into pGEM-T Easy vector, leading to plasmids pBG331 and pBG332, respectively. Plasmids pMUTIN-GFP ${ }^{+}$and pBG331 were KpnI and XmaIII double digested. The $h x l R$-srfAA fragment was inserted between the KpnI and $X m a I I I$ sites of pMUTIN-GFP ${ }^{+}$to obtain pBG334. Then, plasmids pOJ206 and pBG332 were EcoRI and HindIII double digested. The srfAC-srfAC fragment was inserted between the EcoRI and HindIII sites of pOJ206 to obtain plasmid pBG335. In B. subtilis, the surfactin operon was disrupted by targeting two $\operatorname{srfA}$ genes separately. Thus strain BBG201 was successfully transformed by the corresponding vector (pBG334) carrying the fused $h x l R$ $s r f A A: \because g f p$ integrated at the promoter of surfactin operon, disrupting $\operatorname{srfA} A$ and the resulting derivative was named $\mathrm{BBG} 231$. Using the vector $\mathrm{pBG} 335$, the second disruption was performed in $\operatorname{srfAC}$ (after the $\operatorname{srfAB}$-nested comS gene), generating strain BBG232. The hemolytic activity was then checked (data not shown).

\section{Lipopeptide purification and quantification}

$1 \mathrm{ml}$ of supernatant was extracted using C18 cartridges (Extract-clean SPE 500 mg, Grace Davison-Alltech, Deerfield, IL, USA). Lipopeptide production was quantified by HPLC (Waters Corporation, Milford, MA, USA) using a C18 column $(5 \mu \mathrm{m}, 250 \times 4.6 \mathrm{~mm}$, VYDAC $218 \mathrm{TP}$, Hesperia, CA, USA). The measurement of lipopeptides concentration was performed as previously described (Coutte et al. 2010). 


\section{Antifungal assessment}

An about $5 \mathrm{~mm}$ square-sided mycelium mat of the soil-borne fungus Botrytis cinerea was placed on one side of a potato dextrose agar (PDA, MB Cell, Los Angeles, CA, USA), and each bacterial isolate was streaked on the other side of the medium. The PDA plate was incubated at $28{ }^{\circ} \mathrm{C}$ for 4 days. Notably, during the cultivation, the antifungal effects of bacterial isolates were confirmed by inhibition zones formed between the bacterial and fungal isolates. The dual culture was performed at least in three replicates (Kim et al. 2010).

\section{RNA extraction and RT-PCR experiments}

BBG235, BBG236 (pnpA mutant strains), BBG201 and BBG258 (wild-type strains) were inoculated in $50 \mathrm{~mL}$ of Landy MOPS and cultured at $30{ }^{\circ} \mathrm{C}, 160 \mathrm{rev} \mathrm{min}{ }^{-1}$ for $16 \mathrm{~h}$, when the maximum fengycin production was observed (Yaseen et al. 2016). An equivalent volume of about $2^{10}$ cells was obtained from each point of the kinetics previously defined; these volumes were centrifuged $\left(11,000 \mathrm{~g},-9^{\circ} \mathrm{C}\right.$, $5 \mathrm{~min}$ ), the supernatant was discarded, and the pellet was stored in $1 \mathrm{ml}$ Ambion RNA later (Thermo Fisher Scientific) at $-20^{\circ} \mathrm{C}$.

\section{Quantitative PCR}

Total RNA was extracted by re-suspending a culture of about $10^{9}$ cells according to the GeneJET RNA purification Kit (Thermo Scientific Fermentas). The quantity and quality of isolated RNA were determined for each sample by UV absorbance and analyses by agarose gel electrophoresis. Reverse transcription was performed using ReverAid H Minut first Strand cDNA synthesis kit (Thermo Fisher Scientific). Quantitative PCR was performed using StepOnePlus instrument (Applied Biosystems, Foster City, CA, USA). Six primers pairs were designed for the five genes of fengycin operon fenA to fenE and the gene $r r n A$ as a reference gene (Table 2). $2 \mu \mathrm{l}$ of 1:16 cDNA dilution of each strain mixed with $23 \mu \mathrm{l}$ of the master mix (SYBR Green PCR Master Mix, Applied Biosystems), containing $9 \mu \mathrm{l}$ of RNasefree water mixed with $12.5 \mu \mathrm{l} \mathrm{SYBR}$ mix (2X) and $0.75 \mu \mathrm{l}$ of the forward and reverse oligos. All qPCRs were conducted at $95{ }^{\circ} \mathrm{C}$ for 10 min then 40 cycles of $95{ }^{\circ} \mathrm{C}-15 \mathrm{~s}+55^{\circ} \mathrm{C}-30 \mathrm{~s}$ $+72{ }^{\circ} \mathrm{C}-30 \mathrm{~s}$ and finally $95^{\circ} \mathrm{C}$ for $15 \mathrm{~s}+55^{\circ} \mathrm{C}$ for $30 \mathrm{~s}$ and $95{ }^{\circ} \mathrm{C}$ for $15 \mathrm{~s}$. The specificity of the reaction was checked by melting curve analysis. Indeed, melting curve analysis was used to monitor the specificity of the reaction (data not shown). The $2^{-\Delta \Delta C T}$ method was used to calculate the relative gene expression. Accordingly, genes with values under 0.5 are down-regulated, whilst those comprised between 0.5 and 2 are considered as unchanged, and finally genes exhibiting values higher to 2 are considered as up-regulated (Pfaffl 2004; Beltramo et al. 2006).

\section{Results}

\section{Inactivation on the pnpA gene reduced the level of the fengycin production}

To shed light on the role of PNPase on fengycin production, two mutant strains carrying deletion of the pnpA gene were constructed and designated BBG235 and BBG236. Briefly, mutant BBG235 was obtained from BBG201, while BBG236 was obtained from B. subtilis BBG258. Both mutants were characterized morphologically by a multiseptate form (Fig. 2), and a decrease in both fengycin and surfactin productions (Table 3 ).

Production of fengycin in BBG235 was estimated at $96.4 \mathrm{mg} \mu \mathrm{g} \mathrm{L}^{-1}$, and that of the wild type at $346 \mathrm{mg} \mathrm{L}^{-1}$, making a difference of about $72 \%$. Concomitantly, the mutation performed in the pnpA gene affected as well the production of lipopeptide surfactin in BBG235 of about $40 \%$, compared to the parental strain BBG201. The production of surfactin in BBG235 was estimated at $390.4 \mathrm{mg} \mathrm{L}^{-1}$, and that of the wild type at $644 \mathrm{mg} \mathrm{L}^{-1}$. The difference in the fengycin production observed for BBG236 and its parent BBG258 was not as important as that detected for BBG235 and its parent.

A significant decrease in the antifungal activity against the plant pathogen Botrytis cinerea was also observed for BBG235, arguing on the role of PNPase on fengycin production (Fig. 3).

\section{Expression of genes coding for fengycin increased alongside its decrease in production}

The fengycin operon expression was investigated in both BBG235 and BBG236, as well as in the wild-type BBG201 using the qPCR technology. The expression of genes constituting the fengycin operon increased, in both PNPase nullmutants BBG235 and BBG236. Nevertheless, this expression resulted to be exerted in a gene-dependent manner. The upmost expression levels were registered for $f e n B$ and $f e n D$ genes with an enhancement of about 4.2- and 3.8-fold, respectively. In spite of this enhancement, production of fengycin decreased in both BBG235 and BBG236 (Fig. 4).

\section{Effects of location of srf mutations on fengycin production}

To see whether there is any interplay between surfactin and fengycin regulations, derivatives carrying mutations in the 
Fig. 2 The multi-septate form of the pnpA mutant strains versus wild-type strains: a BBG235, b BBG201, c BBG236, d BBG258 $\mathbf{a}$

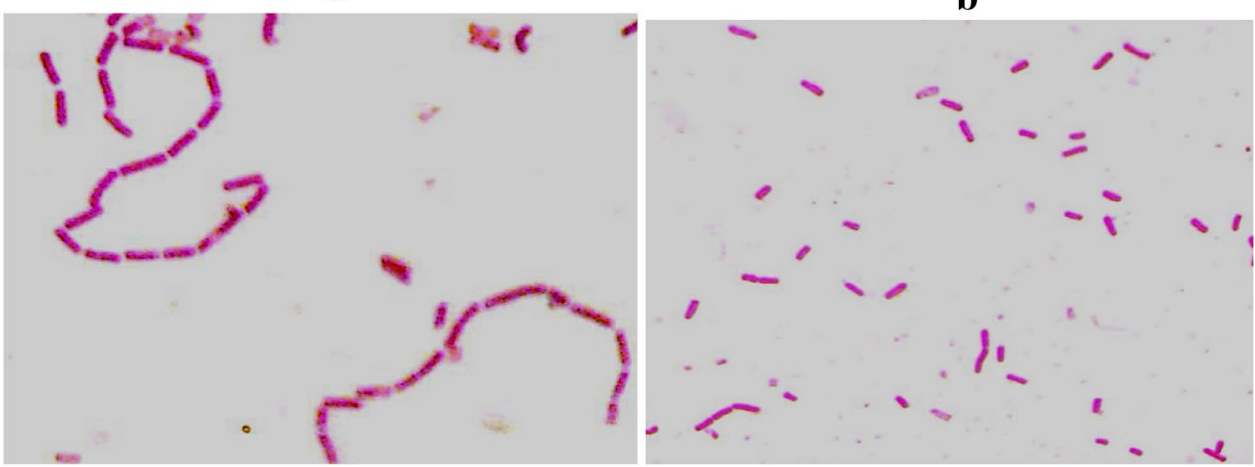

\section{c}

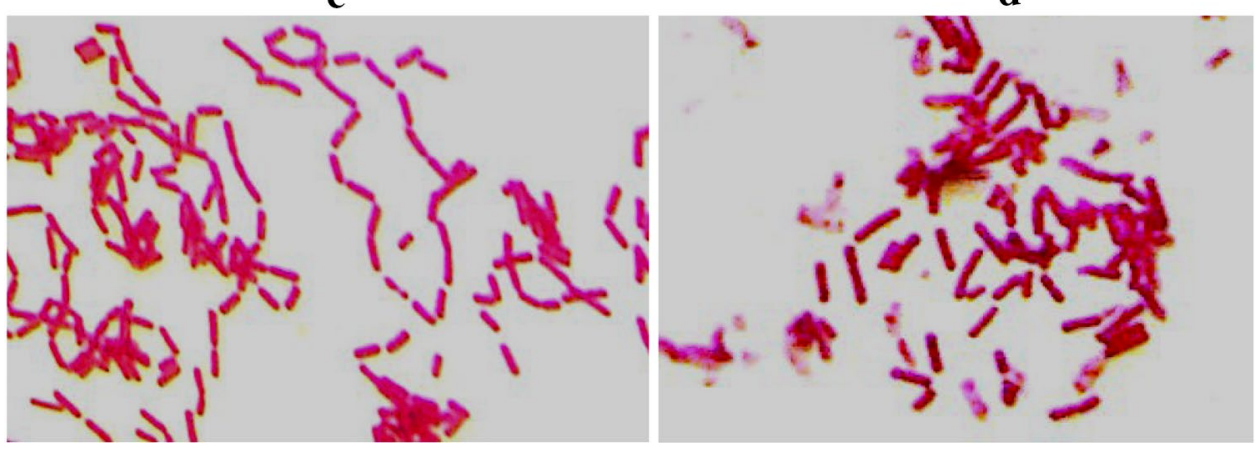

Table 3 Lipopeptide production in batch by four strains of $B$. subtilis after $48 \mathrm{~h}$ of growth in Landy MOPS medium, $\mathrm{pH} 7$, $10 \%$ filling ratio, at $30{ }^{\circ} \mathrm{C}$ and $160 \mathrm{rev} \mathrm{min}^{-1}$

\begin{tabular}{|c|c|c|c|c|}
\hline Strain & Fengycin $\left(\mathrm{mg} \mathrm{L}^{-1}\right)$ & $\begin{array}{l}\text { Fengycin }(\mathrm{mg} \\
\left.\mathrm{L}^{-1} \cdot \mathrm{OD}_{600}\right)\end{array}$ & Surfactin $\left(\mathrm{mg} \mathrm{L}^{-1}\right)$ & $\begin{array}{l}\text { Surfactin } \\
\left(\mathrm{mg}^{\mathrm{L}-1} \text {. }\right. \\
\left.\mathrm{OD}_{600}\right)\end{array}$ \\
\hline BBG21 (wild type) & $346.0 \pm 12.3$ & $37.6 \pm 3.2$ & $644.0 \pm 22.2$ & $70.7 \pm 2.1$ \\
\hline 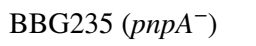 & $96.4 \pm 11.4$ & $13.2 \pm 1.8$ & $390.4 \pm 23.7$ & $54.1 \pm 3.3$ \\
\hline BBG258 (wild type) & $20.34 \pm 1.32$ & $2.2 \pm 0.9$ & $746.4 \pm 17.3$ & $81.3 \pm 5.3$ \\
\hline $\mathrm{BBG} 236\left(p n p A^{-}\right)$ & $7.4 \pm 1.1$ & $0.98 \pm 0.3$ & $478.0 \pm 11.1$ & $63.7 \pm 4.3$ \\
\hline
\end{tabular}

surfactin operon were constructed. The fengycin and surfactin productions were quantified in the wild-type and the derived strains as depicted in Table 4. As expected, surfactin production was altered in both BBG231 and BBG232. In these strains, the amount of fengycin had decreased from $385 \mathrm{mg} \mathrm{L}^{-1}$ (wild-type BBG201) to $76.4 \mathrm{mg} \mathrm{L}^{-1}$ (mutant BBG231), but not for the mutant BBG232 disrupted in the srfAC gene.

\section{Discussion}

After 60 years of investigation on the fascinating $3^{\prime}-5^{\prime}$ exoribonuclease PNPase, we are far from deciphering the final role of this unessential but important and abundant enzyme. B. subtilis altered for PNPase activity has diverse phenotypes as a long multi-septate form, sensitivity to low temperatures, and antibiotics resistance, deficiency for DNA competence (Luttinger 1996; Cardenas et al. 2009).

Further implications of PNPase in cell biology, specifically on the biosynthesis of lipopeptide fengycin are provided here. To this end, mutant strains altered for PNPase activity were conceived, constructed and assessed for fengycin production. It is noteworthy that $B$. subtilis BBG235, the strain carrying the $p n p A$ gene disruption, displayed a decrease of about $70 \%$ in fengycin production. Attempts to link PNPase activity to this decrease in the fengycin production were performed. Expression of genes coding for fengycin, as studied by qPCR technology, revealed significant enhancement of $f e n B$ and $f e n D$ in BBG235 and BBG236, which carry a mutation in the pnpA gene. This data advocates the involvement of PNPase in the control of fengycin expression.

Another hypothesis to explain the decrease in fengycin production in BBG235 and BBG236 could be associated 


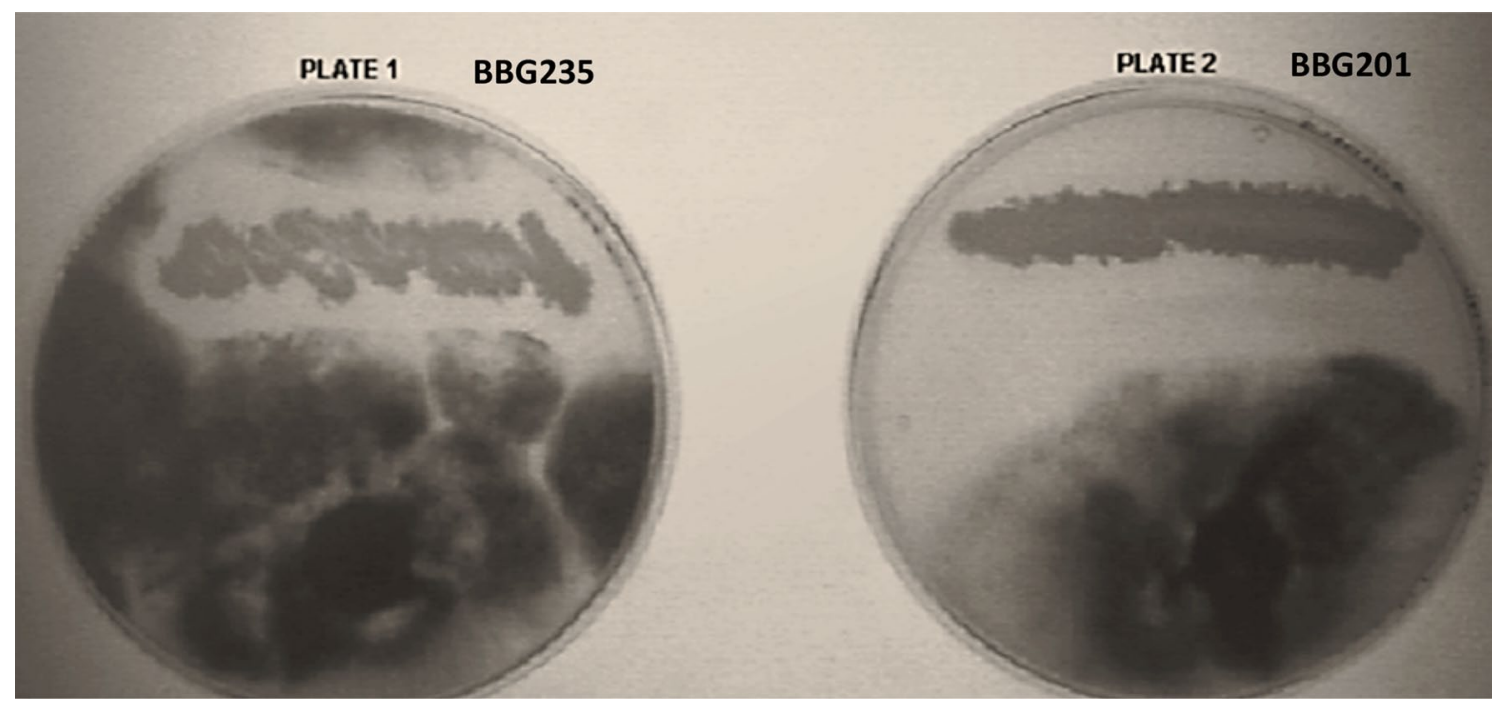

Fig. 3 In vitro growth inhibition of Botrytis cinerea caused by the mutant strain BBG235 (Plate 1) and the wild-type strain BBG201 (Plate 2) on potato dextrose agar (PDA) medium. The antagonism was inspected after incubation of the plates for 3 days at $25^{\circ} \mathrm{C}$
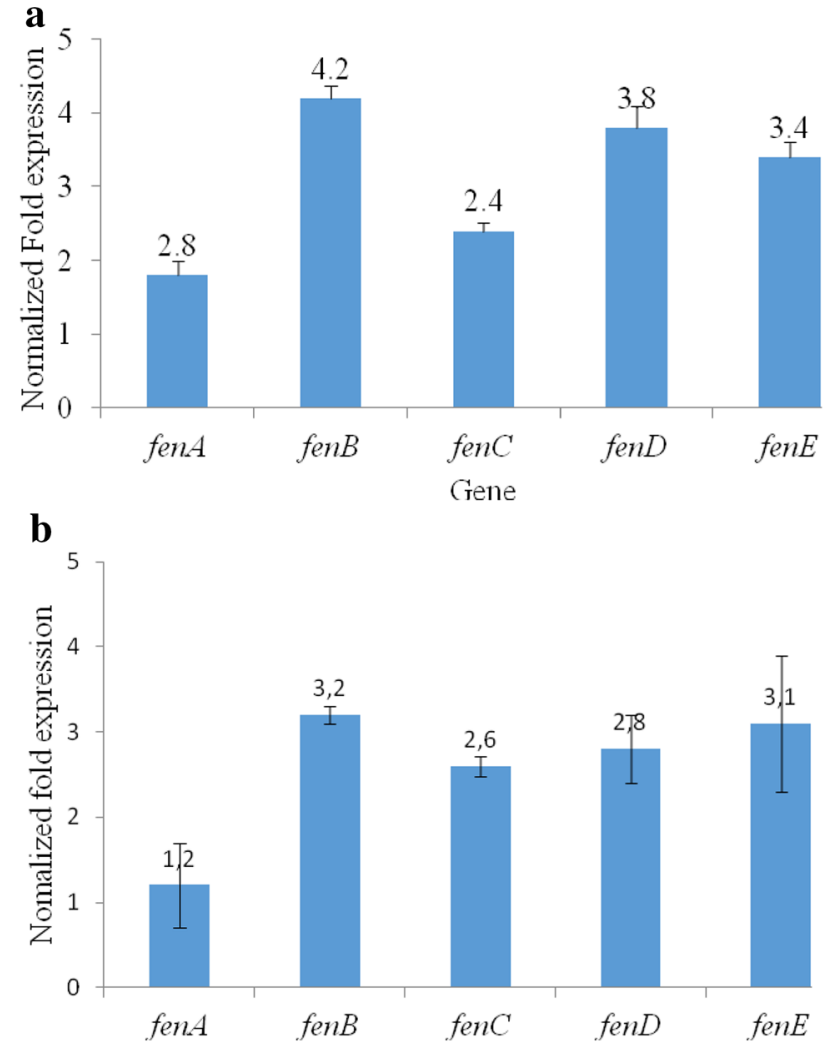

Fig. 4 Relative fengycin genes expressions from the $p n p A$ mutant strains. The expression was measured using the quantitative PCR technique using the wild-strain BBG201 as control and the gene $r r n A$ as reference gene. The expressions were obtained after incubation of the bacteria in $50 \mathrm{~mL}$ of Landy MOPS at $30{ }^{\circ} \mathrm{C}, 160 \mathrm{rev} \mathrm{min}^{-1}$ for $16 \mathrm{~h}$. The $2^{-\Delta \Delta C T}$ method was used to calculate the relative gene expressions. a BBG235 and b BBG236 with expressions of both comS gene and srfA operon, which code for a competence factor and the lipopeptide surfactin, respectively. It should be noted that early report from Luttinger et al. (1996) unveiled already the effect of PNPase on surfactin production through the control of $\operatorname{comS}$ gene. A recent report from Gamba et al. (2015) confirmed the role of PNPase on comS gene expression. Taking the aforementioned studies and our data together, we can postulate on a lead of PNPase on biosynthesis of fengycin via a complex regulatory system involving coms gene, or a direct control of mRNAs from fengycin operon.

The influence of $p n p A$ on the fengycin production may occur via different pathways. Commichau et al. (2009) and Salvo et al. (2016) have postulated that PNPase interacts with enolase and phosphofructokinase, which are essential enzymes for glycolytic pathway. Based on data gathered in this study, we hypothesize therefore that $p n p A$ gene deletion may afflict the precursor synthesis for the carbon metabolism, which ultimately impacts the lipopeptide production.

Moreover, Liu et al. (2016) have recently reported that B. subtilis deficient in PNPase activity displayed a high expression of regulator $\operatorname{sig} B$ gene. Interestingly, the product of $\operatorname{sig} B$ gene was recently shown to exert a repressing effect on fengycin operon expression (Allenby et al. 2005).

Zhao et al. (2016) have utilized a genome shuffling approach to increase production of fengycin in $B$. amyloliquefaciens ES-2-4. Thus, after two rounds of genome shuffling, the authors noticed a rise in biosynthesis of fengycin of about 8.9-fold, and linked this rise to important expression of fengycin synthetase gene $(f e n A)$, which was 12.77 -fold greater in the shuffling strains than in the parental strain ES-2-4. 
Table 4 Lipopeptide production in Landy MOPS medium, $\mathrm{pH} 7,10 \%$ filling ratio, at $30{ }^{\circ} \mathrm{C}$ and $160 \mathrm{rev} \min ^{-1}$, after $48 \mathrm{~h}$ by $B$. subtilis $\mathrm{BBG} 201$ and $s f r$ mutants (BBG231 and BBG232)

\begin{tabular}{lccc}
\hline Strain & Fengycin $\left(\mathrm{mg} \mathrm{L}^{-1}\right)$ & Fengycin $\left(\mathrm{mg} \mathrm{L}^{-1} \cdot \mathrm{OD}_{600}\right)$ & Surfactin $_{\left(\mathrm{mg} \mathrm{L}^{-1}\right)}$ \\
\hline BBG201 (wild-type) & $385.0 \pm 16.3$ & $35.0 \pm 2.9$ & $644.0 \pm 22.2$ \\
BBG231 (sfrAA-) & $76.4 \pm 5.6$ & $8.4 \pm 0.9$ & 0.0 \\
BBG232 $\left(s f r A C^{-}\right)$ & $402.6 \pm 21.4$ & $37.9 \pm 3.3$ & 0.0 \\
\hline
\end{tabular}

The data obtained in this study indicate that PNPase could interfere with fengycin production through the product of $s r f A A$ or $c o m S$, which regulate the natural competence in Bacillus via comK. Remarkably, comK gene was reported to negatively regulate $\operatorname{deg} Q$ expression (Ogura et al. 2002), which is a regulator of fengycin operon (Tsuge et al. 1999).

On the other hand, production of different lipopeptides within a same strain might be subjected to any interplay and switch-on or switch-off regulations. Related to this, Karatas et al. (2003) reported that bacilysin production in B. subtilis ATCC 21332 decreased when this strain was devoid of SrfA activity. In direct line, Béchet et al. (2013) mentioned similar impact of $s r f A A$ mutation on mycosubtilin production in $B$. subtilis ATCC 6633. Inversely, we reported that disruption of fenA gene led to $30 \%$ enhancement of surfactin production in B. subtilis (Yaseen et al. 2016).

To examine the impact of surfactin-codifying DNA on fengycin production, we assessed production of this lipopeptide in B. subtilis BBG231 and BBG232. While no effect was registered for BBG232 (srfAC mutant), a significant decrease in fengycin production was noticed for BBG231, arguing on the role of $s r f A A / c o m S$ in fengycin production. These data are in good agreement with those previously reported by Ongena et al. (2007) who indicated the absence of any effect on fengycin production in B. subtilis 168 , when harboring deletions of the $\operatorname{srfAB}$, srfAC and $\operatorname{srf} A D$ genes. Another point that needs to be underlined is the role of PNPase on the antifungal activity. Related to this, we noticed a decrease of the antifungal activity in $B$. subtilis carrying mutations in pnpA and srfAA genes. In direct line, Zeriouh et al. (2014) reached a similar conclusion for $B$. subtilis carrying a mutation in the $s f r A B$ gene.

\section{Conclusion}

This study showed the global regulatory role of PNPase on fengycin production. Indeed, the knock-out of $p n p A$ gene in $B$. subtilis resulted in a decrease in fengycin production, compared to the parental strain. To the best of knowledge, this is the first report underpinning the impact of PNPase activity on fengycin production. Besides, we showed the effect of $s r f$ operon on fengycin production, therefore opening a new avenue aiming at understanding the interplay between genes coding for lipopeptides within a same strain.

Acknowledgements YY was a recipient of PhD scholarship awarded by Campus France through joint French-Iraqi governments program. The authors express their gratitude for "Région des Hauts-de-France" for CPER-FEDER Alibiotech project.

\section{Compliance with ethical standards}

Conflict of interest The authors declare no conflicts of interest for this article.

\section{References}

Allenby NE, O’Connor N, Prágai Z, Ward AC, Wipat A, Harwood CR (2005) Genome-wide transcriptional analysis of the phosphate starvation stimulon of Bacillus subtilis. J Bacteriol 187:8063-8080

Béchet M, Castéra-Guy J, Guez JS, Chihib NE, Coucheney F, Coutte F, Leclère V, Wathelet B, Jacques P (2013) Production of a novel mixture of mycosubtilins by mutants of Bacillus subtilis. Bioresour Technol 145:264-270

Beltramo C, Desroche N, Tourdot-Maréchal R, Grandvalet C, Guzzo J (2006) Real-time PCR for characterizing the stress response of Oenococcus oeni in a wine-like medium. Res Microbiol 157:267-274

Briani F, Carzaniga T, Deho G (2016) Regulations and functions of bacterial PNPase. Wiley Interdiscip Rev RNA 7:241-258

Cao G, Zhang X, Zhong L, Lu Z (2011) A modified electro-transformation method for Bacillus subtilis and its application in the production of antimicrobial lipopeptides. Biotechnol Lett 33:1047-1051

Cardenas P, Carrasco B, Sanchez H, Deikus G, Bechhofer H, Alonso JC (2009) Bacillus subtilis polynucleotide phosphorylase 3'-to5 ' DNase activity is involved in DNA repair. Nucleic Acids Res 37(12):4157-4169

Ceresa C, Rinaldi M, Chiono V, Carmagnola I, Allegrone G, Fracchia L (2016) Lipopeptides from Bacillus subtilis AC7 inhibit adhesion and biofilm formation of Candida albicans on silicone. Antonie Van Leeuwenhoek 109:1375-1388

Chen XH, Koumoutsi A, Scholz R, Eisenreich A, Schneider K, Heinemeyer I, Morgenstern B, Voss B, Hess WR, Reva O, Junge H, Voigt B, Jungblut PR, Vater J, Süssmuth R, Liesegang H, Strittmater A, Gottschalk G, Borriss R (2007) Comparative analysis of the complete genome sequence of the plant growth-promoting bacterium Bacillus amyloliquefaciens FZB42. Nature Biotechnol 25:1007-1014

Cheng W, Feng YQ, Ren J, Jing D, Wang C (2016) Anti-tumor role of Bacillus subtilis fmbJ-derived fengycin on human colon cancer HT29 cell line. Neoplasma 63:215-222 
Commichau FM, Rothe FM, Herzberg C, Wagner E, Hellwig D, LehnikHabrink M et al (2009) Novel activities of glycolytic enzymes in Bacillus subtilis: interactions with essential proteins involved in mRNA processing. MolCell Proteom 8:1350-1360

Coutte F, Lecouturier D, Yahia SA, Leclère V, Béchet M, Jacques P, Dhulster P (2010) Production of surfactin and fengycin by Bacillus subtilis in a bubbleless membrane bioreactor. Appl Microbiol Biotechnol 87:499-507

Dhali D (2016) Correlation between lipopeptides biosynthesis and their precursor metabolism in Bacillus subtilis. PhD Thesis, Lille1 University, France

Duitman EH, Wyczawski D, Boven LG, Venema G, Kuipers OP, Hamoen LW (2007) Novel methods for genetic transformation of natural Bacillus subtilis isolates used to study the regulation of the mycosubtilin and surfactin synthetases. Appl Environ Microbiol 73:3490-3496

Fahim S, Dimitrov K, Gancel F, Vauchel P, Jacques P, Nikov I (2012) Impact of energy supply and oxygen transfer on selective lipopeptide production by Bacillus subtilis BBG21. Bioresour Technol 126:1-6

Galli G, Rodriguez F, Cosmina P, Pratesi C, Nogarotto R, de Ferra F, Grandi G (1994) Characterization of the surfactin synthetase multienzyme complex. Biochim Biophys Acta (BBA) Protein Struct Mol Enzymol 1205:19-28

Gamba P, Jonker MJ, Hamoen LW (2015) A novel feedback loop that controls bimodal expression of genetic competence. PLoS Genet 11:e1005047

Hamoen W, Eshuis H, Jongbloed J, Venema G, Sinderen D (1995) A small gene, designated comS, located within the coding region of the fourth amino acid-activation domain of $s r f A$, is required for competence development in Bacillus subtilis. Mol Microbiol 15:55-63

Hussein W (2011) Study on the regulation and biosynthesis of fengycin and plipastatin produced by Bacillus subtilis. PhD Thesis, Lille1 University, France

Iatsenko I, Yim JJ, Schroeder FC, Sommer RJ (2014) B. subtilis GS67 protects $C$. elegans from Gram-positive pathogens via fengycinmediated microbial antagonism. Curr Biol 24:2720-2727

Jacques P (2011) Surfactin and other lipopeptides from Bacillus spp. In: Soberon-Chavez G (ed) Biosurfactants microbiology monographs, vol 20. Springer, Berlin, pp 57-91

Kakiuchi N, Fukui T, Ikehara M (1979) Polynucleotides. LVII. Synthesis and properties of poly (2'chloro-2'-deoxyinosinic acid). Nucleic Acid Res 6:2627-2636

Karatas Y, Çetin S, Özcengiz G (2003) The effects of insertional mutations in comQ, comP. srfA, spoOH, spoOA and $a b r B$ genes on bacilysin biosynthesis in Bacillus subtilis. Biochim Biophys Acta (BBA) Gene Struct Express 1626:51-56

Kim I, Ryu J, Kim H, ChI YT (2010) Production of biosurfactant lipopeptides iturin A, fengycin and surfactin A from Bacillus subtilis CMB32 for control of Colletotrichum gloeosporioides. J Microbiol Biotechnol 20:138-145

Landy M, Warren GH, Rosenman SB, Colio LG (1948) Bacillomycin an antibiotic from Bacillus subtilis active against pathogenic fungi. Proc Soc Exp Biol Med 67:530-541

Lee K, Yoon D, Yoon H, Lee G, Song J, Kim G, Kim S (2007) Cloning of srfA operon from Bacillus subtilis $\mathrm{C} 9$ and its expression in E. coli. Appl Microbiol Biotechnol 7:567-572

Liu L, Nakano M, Lee H, Zuber P (1996) Plasmid-amplified comS enhances genetic competence and suppresses sinR in Bacillus subtilis. J Bacteriol 178:5144-5152

Liu B, Deikus G, Bree A, Durand S, Kearns B, Bechhofer DH (2014) Global analysis of mRNA decay intermediates in Bacillus subtilis wild-type and polynucleotide phosphorylase-deletion strains. Mol Microbiol 94:41-55

Liu B, Daniel B, David H (2016) Expression of multiple Bacillus subtilis genes is controlled by decay of slrA mRNA from Rho-dependent $3^{\prime}$ ends. Nucleic Acids Res 44(7):3364-3372
Luttinger A, Hahn J, Dubnau D (1996) Polynucleotide phosphorylase is necessary for competence development in Bacillus subtilis. Mol Microbiol 19:343-356

Nakano M, Zuber P (1991) The primary role of ComA in establishment of the competent state in Bacillus subtilis is to activate expression of srfA. J Bacteriol 173:7269-7274

Nakano MM, Magnuson R, Myers A, Curry J, Grossman AD, Zuber P (1991) srfA is an operon required for surfactin production, competence development, and efficient sporulation in Bacillus subtilis. J Bacteriol 173:1770-1778

Ogura M, Yamaguchi H, Kobayashi K, Ogasawara N, Fujita Y, Tanaka $\mathrm{T}$ (2002) Whole-genome analysis of genes regulated by the Bacillus subtilis competence transcription factor ComK. J Bacteriol 184:2344-2351

Ongena M, Jourdan E, Adam A, Paquot M, Brans A, Joris B, Arpigny L, Thonart P (2007) Surfactin and fengycin lipopeptides of Bacillus subtilis as elicitors of induced systemic resistance in plants. Environ Microbiol 9:1084-1090

Pfaffl MW (2004) Quantification strategies in real-time polymerase chain reaction. In: Bustin SA (ed) A-Z of quantitative PCR, IUL biotechnology Series. International University Lines, La Jolla, pp 87-120

Roongsawang N, Thaniyavarn J, Thaniyavarn S, Kameyama T, Haruki M, Imanaka T, Kanaya S (2002) Isolation and characterization of a halotolerant Bacillus subtilis BBK-1 which produces three kinds of lipopeptides: bacillomycin L, plipastatin, and surfactin. Extremophiles 6:499-506

Roongsawang N, Washio K, Morikawa M (2010) Diversity of nonribosomal peptide synthetases involved in the biosynthesis of lipopeptide biosurfactants. IntJ Mol Sci 12:141-172

Salvo E, Alabi S, Liu B, Schlessinger A, Bechhofer DH (2016) Interaction of Bacillus subtilis polynucleotide phosphorylase and RNase Y: structural mapping and effect on mRNA turnover. J Biol Chem 291(13):6655-6663

Sambrook J, Russell DW (2001). Molecular cloning: a laboratory manual, 3rd edn. Cold Spring Harbor Laboratory, New York

Schultz D, Wolynes G, Jacob B, Onuchic N (2009) Deciding fate in adverse times: sporulation and competence in Bacillus subtilis. Proc Natl Acad Sci (USA) 106:21027-21034

Sinchaikul S, Sookkheo B, Topanuruk S, Juan HF, Phutrakul S, Chen ST (2002) Bioinformatics, functional genomics, and proteomics study of Bacillus sp. J Chromatog B 771:261-287

Stein T (2005) Bacillus subtilis antibiotics: structures, syntheses and specific functions. Mol Microbiol 56:845-857

Steller S, Vollenbroich D, Leenders F, Stein T, Conrad B, Hofemeister J, Vater J (1999) Structural and functional organization of the fengycin synthetase multienzyme system from Bacillus subtilis b213 and A1/3. Chem Biol 6:31-41

Tang Q, Bie X, Lu Z, Lv F, Tao Y, Qu X (2014) Effects of fengycin from Bacillus subtilis fmbJ on apoptosis and necrosis in Rhizopus stolonifer. J Microbiol 52:675-680

Tsuge K, Ano T, Hirai M, Nakamura Y, Shoda M (1999) The genes degQ. pps, and lpa-8 ( $s f p)$ are responsible for conversion of Bacillus subtilis 168 to plipastatin production. Antimicrob Agents Chemother 43:2183-2192

Yaseen Y, Gancel F, Drider D, Béchet M, Jacques P (2016) Influence of promoters on the production of fengycin in Bacillus spp. Res Microbiol 176:272-281

Zeriouh H, Vicente A, Pérez-García A, Romero D (2014) Surfactin triggers biofilm formation of Bacillus subtilis in melon phylloplane and contributes to the biocontrol activity. Environ Microbiol 16:2196-2211

Zhao J, Zhang C, Lu J, Lu Z (2016) Enhancement of fengycin production in Bacillus amyloliquefaciens by genome shuffling and relative gene expression analysis using RT-PCR. Can J Microbiol 62:431-436 